\title{
The current pathogens and treatment of hospital- acquired pneumonia/ventilator-associated pneumonia in medical intensive care units
}

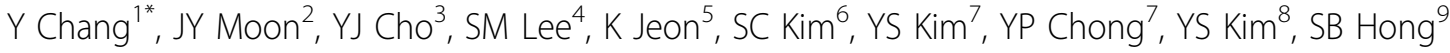 \\ From ESICM LIVES 2015 \\ Berlin, Germany. 3-7 October 2015
}

\begin{abstract}
Introduction
Because of increasing prevalence of multi-drug resistant (MDR) pathogens, there are many difficulties in the treatment of hospital-acquired pneumonia (HAP)/ventilatorassociated pneumonia (VAP). It is known that patients with MDR pathogens have high mortality and morbidity. We need to know the current status of pathogens and antibiotics therapy for a proper choice of initial antibiotics to improve outcome of the patients.
\end{abstract}

\section{Objectives}

This study was aimed at investigating the current pathogens and treatment of HAP/VAP in Korean ICUs. Methods A prospective, multicenter and observational study was conducted in six tertiary referral hospitals in Korea between August 1, 2012 and July 31, 2013. This study included patients who were admitted to adult medical ICUs with diagnosed as pneumonia developing at least 48 hours after admission or initiation of mechanical ventilation. We analyzed the prevalence of their pathogens, and treatment and clinical courses of these patients.

\section{Results}

During the study period of 12 months, total 134 patients with HAP/VAP were enrolled. Mean age was 65 with 103 (77\%) males. Forty-seven (35\%) patients had risk factors of MDR pathogens. The duration between admission and diagnosis of pneumonia was 12 days (IQR: 7-22 days). Most of patients (86\%) underwent mechanical ventilation. Pathogens were identified in

\footnotetext{
${ }^{1}$ Chungbuk National Univ. Hospital, Chungbuk National University College of Medicine, Division of Pulmonary and Critical Care Medicine, Department of Internal Medicine, Cheongju, Korea, Republic of

Full list of author information is available at the end of the article
}

79 (59\%) patients. Among them, MDR bacteria were isolated in $55(76 \%)$ patients. The most common MDR pathogen was carbapenem-resistant Acinetobacter baumannii (60\%). However, extended-spectrum penicillin $/ \beta$ lactamase inhibitor-based was the most common empirical antibiotics (39\%) during initial 48 hours after diagnosis. Glycopeptides were used in 60 patients (47\%). As a subsequent therapy between 48 hours and 2 weeks after diagnosis, carbapenem-based regimen was most common (36\%). On the other hand, colistin-based therapy was done in $29(22 \%)$ patients. Only $45(34 \%)$ patients showed a clinical resolution within 28 days. They showed a high in-hospital mortality of $51 \%$ with 28 -day and 60 -day of $31 \%$ and $49 \%$, respectively.

\section{Conclusions}

This study demonstrates that carbapenem-resistant A. baumannii is the most common MDR pathogen in Korean medical ICUs. It shows that there is a discrepancy between the common MDR pathogen and the choice of empirical antibiotic therapy.
Authors' details

'Chungbuk National Univ. Hospital, Chungbuk National University College of Medicine, Division of Pulmonary and Critical Care Medicine, Department of Internal Medicine, Cheongju, Korea, Republic of. ${ }^{2}$ Chungnam National Univ. Hospital, Chungnam National University College of Medicine, Division of Daejeon, Korea, Republic of. ${ }^{3}$ Seoul National University Bundang Hospital, Seoul National University College of Medicine, Division of Pulmonary and Critical Care Medicine, Department of Internal Medicine, Seongnam, Korea, Republic of. ${ }^{4}$ Seoul National University Hospital, Seoul National University College of Medicine, Division of Pulmonary and Critical Care Medicine, Department of Internal Medicine, Seoul, Korea, Republic of. ${ }^{5}$ Samsung Medical Center, Sungkyunkwan University School of Medicine, Department of Pulmonary and Critical Care Medcine, Seoul, Korea, Republic of. 'St.Mary's Hospital, The Catholic University of Korea, Division of Pulmonology, Department of Internal Medicine, Seoul, Korea, Republic of. ${ }^{7}$ Asan Medical 
Center, University of Ulsan College of Medicine, Department of Infectious Diseases, Seoul, Korea, Republic of. ${ }^{8}$ Severance Hospital, Yonsei University College of Medicine, Division of Pulmonology, Department of Internal Medicine, Seoul, Korea, Republic of. ${ }^{9}$ Asan Medical Center, University of Ulsan College of Medicine, Department of Pulmonary and Critical Care

Medicine, Seoul, Korea, Republic of.

Published: 1 October 2015

\section{References}

1. Weber DJ, Rutala WA, Sickbert-Bennett EE, et al: Infect Control Hosp Epidemiol. 2007, 28(825).

2. Kollef MH, Morrow LE, Niederman MS, et al: Chest 2006, 129(1210).

3. American Thoracic Society, Infectious Diseases Society of America: Am J Respir Crit Care Med 2005, 171(388)

4. Kollef MH, Shorr A, Tabak YP, et al: Chest 2005, 128-3854.

5. Paterson DL: Clin Infect Dis 2006, 43(Suppl 2):S43.

doi:10.1186/2197-425X-3-S1-A707

Cite this article as: Chang et al.: The current pathogens and treatment of hospital-acquired pneumonia/ventilator-associated pneumonia in medical intensive care units. Intensive Care Medicine Experimental 2015

3(Suppl 1):A707.

\section{Submit your manuscript to a SpringerOpen ${ }^{\mathcal{O}}$ journal and benefit from:}

- Convenient online submission

- Rigorous peer review

- Immediate publication on acceptance

- Open access: articles freely available online

- High visibility within the field

- Retaining the copyright to your article

Submit your next manuscript at $\gg$ springeropen.com 